\title{
Original Articles \\ MYELOPATHY ASSOCIATED WITH SYSTEMIC LUPUS ERYTHEMATOSUS (Erythema Nodosum)
}

\author{
L. S. Kewalramani, M.D., M.S.Orth., S. SaleEM, M.D. and \\ D. BERTRAND, M.T. (ASCP) \\ Texas Institute for Rehabilitation and Research and Department of Pathology, \\ Baylor College of Medicine, Houston, Texas 77030, U.S.A.
}

Abstract. Two patients with sudden onset of myelopathy associated with Systemic Lupus Erythematosus (Erythema Nodosum) are described. Pertinent literature is extensively reviewed and these two new patients are added to previously reported 26 patients.

Key words: Myelopathy; Meningoencephalomyelopathy; Systemic lupus erythematosus.

Neurological manifestations of systemic lupus erythematosus (SLE) have only recently been emphasised although they were mentioned by Kaposi in 1875 , who observed stupor and coma as terminal manifestations of the disease. But focal neurological abnormalities were first reported by Osler (1903) and since then there have been several reports in the literature. Most commonly reported entities have been acute organic brain syndrome, seizures and cerebrovascular disorders. Chorea, Guillain Barré syndrome, subarachnoid haemorrhage, peripheral neuropathy and cranial nerve palsies associated with SLE have also been reported on a few occasions. Myelopathy, however, has not received adequate emphasis as a complication of SLE.

Fisher and Gilmour reported the first case of flaccid paraplegia in a female with SLE in 1939. Since then only 25 additional cases have been reported in the medical literature over the past 38 years. Twenty cases have been described in sufficient detail and six briefly, to permit a meaningful review of the spinal cord involvement in this disease. We feel that there are probably many more unreported cases of myelopathy associated with SLE. The objective of this paper is to report two new cases of myelopathy in which myelopathy was the initial major manifestation of SLE. Both patients were found to have defect on myelography and underwent exploratory laminectomy. Some important features with a follow-up on two cases previously reported by Andrianakos, Duffy, Suzuki and Sharp (1975) will be described since these patients were also admitted at the Texas Institute for Rehabilitation and Research. The pertinent literature will also be reviewed in depth.

\section{Materials and Methods}

Since January I960 through December I977, I350 patients with lesions of the spinal cord have been admitted at the Texas Institute for Rehabilitation and Research, Houston. Medical records of these patients were reviewed. There were four patients admitted with myelopathy secondary to SLE. The admission of cases I and 2 under the care of the senior author prompted this search.

* Supported in part by Rehabilitation Research \& Training Center No. 4 (RSA Grant 6-P-56813/6-I6). 


\section{Case I}

\section{Case Reports}

A 28-year-old black female was admitted to the Texas Institute for Rehabilitation and Research on 27 September 1977 for comprehensive rehabilitation. In May 1977 she noted periorbital swelling and generalised oedema over upper and lower limbs. She was seen by her local physician who found her to be hypertensive with proteinuria. She was treated with Lasix, penicillin and prednisone. Her oedema improved and prednisone was gradually tapered and all medications were stopped after about 3 weeks. On 5 June I 977 she developed severe pain in the upper and middle parts of back, nausea, vomiting, chills and high fever. Back pain was deep seated with no radiation. Approximately I2 hours after the onset of back pain she noted numbness and weakness of lower extremities and within the next 8 hours she became tetraplegic. At the time of her admission to the hospital her temperature was $101 \cdot 4^{\circ} \mathrm{F}$ and blood pressure of $160 / 100 \mathrm{~mm} \mathrm{Hg}$. There were erythematous punctate lesions without crust over the left upper lip and left nasal bridge. There was a small port wine stain on the left nose, and left buccal area, which she has had all her life. There was marked nuchal rigidity with diffused tenderness along the cervical region. She had loss of touch and pin prick below $\mathrm{C}_{7}$ dermatome. Position and vibratory sense in the lower limbs were intact. She had loss of motor power below the C5 myotome level. Superficial and deep tendon reflexes were absent. Plantar response was also absent bilaterally. Straight leg raising test was positive bilaterally at $70-80^{\circ}$. Lumbar myelogram showed partial block from T8-T6 and a total block at TI. Cervical myelogram showed a total block at $\mathrm{C}_{5}$. She underwent a cervical and thoracic laminectomy on 6 June 1977, but no evidence of any pathology could be found; except for slightly thickened dura and pale epidural fat. Following surgery myelogram was repeated, which was reported to be normal. Elevated temperature responded well to prednisone therapy. In December 1977, the patient was still tetraplegic below C8 with neurological picture of anterior cervical cord syndrome.

Laboratory data: Haemoglobin $9 \cdot 4 \mathrm{gm} \%$, haematocrit $29 \cdot \mathrm{I} \%$, white cell count $7400 / \mathrm{mm}^{3}$. Sedimentation rate $6 \mathrm{I} \mathrm{mm} / \mathrm{hr}$. CSF: (6-6-77) protein $88 \mathrm{mg} \%$, glucose $29 \mathrm{mg} \%$, white cells 26 with $8 \mathrm{I} \%$ polys and $5 \%$ mononuclears. Several assays of complement were normal except on one occasion, Complement $\mathrm{C}_{3}$ was reported low. ANA and LE preparations were negative on four occasions, when patient was on prednisone. Subsequently, when the patient was taking only $5 \mathrm{mg}$ of prednisone, ANA was positive on two occasions and LE prep. positive once. VDRL negative, RA negative. Serum protein electrophoresis showed reversal of A/G ratio. CSF and blood cultures on several occasions were reported negative. Renal biopsy findings were reported to be consistent with chronic membrano proliferative glomerulonephritis. Biopsy of dura matter and epidural fat showed dense connective and fibroadipose tissue with perivascular hyalinisation. Chest X-rays showed mild cardiomegaly. Radiographs of the spine revealed osteoporosis and crack undisplaced fracture through the vertebral body of T5 at 5 weeks after the laminectomy; this was not present on the initial films. Sensory and motor nerve conduction studies for median, ulnar, tibial and peroneal nerves were normal.

Comment: LE preparation and ANA were negative in the beginning when the patient was on heavy doses of steroids, 3 months later ANA was positive on two occasions and LE cell preparation was positive on one. This patient according to ARA criteria and criteria set by Dubois was a definite case of SLE.

\section{Case 2}

This 53-year-old black female on I4 January 1976 noted a dull, deep-seated midscapular pain which radiated in a band-like distribution around the chest and sternum. Approximately 12 hours after the onset of pain, she noted numbness and weakness in the lower extremities progressing over a 2-hour period to complete paraplegia. She had noted vague neck pains for several days, and 4 days prior to admission she had complained 
of feverishness, chilly sensation and sore throat along with right ear ache. At the time of her admission, patient had diffuse tenderness in the mid-scapular region to direct palpation. Deep tendon reflexes were absent in the lower extremities. Plantar response was neutral. Patient had no voluntary activity in the lower limbs. She had loss of pin prick below $\mathrm{T}_{5}$ with some preserved touch and pressure sensation in the lower limbs. Since myelogram showed a block at the T8 level she underwent laminectomy $\mathrm{T}_{7}$-IO. Spinal cord was reported to be normal with no evidence of pathologic block during surgery. Epidural fat was reported to be soft, pale and of 'unnatural colour'. She had some hyperpigmentation of the right cheek. Spleen was palpable two finger breadths below the costal margin.

During hospitalisation, the patient developed haemolytic anaemia and her haemoglobin dropped to $5.9 \mathrm{gm} \%$. Anaemia responded very well to prednisone therapy. Patient's neurological status remained unchanged, i.e. paraplegia below $\mathrm{T}_{5}$ with some preservation of touch and pressure sensation.

Laboratory data: Haemoglobin $7 \cdot 4 \mathrm{gm} \%$. Coomb's test positive direct and indirect. CSF (I-I4-76) protein $585 \mathrm{mg} \%$, glucose $3 \mathrm{I} \mathrm{mg \%}$ and white cells 425 with $50 \%$ polymorphonuclears. Serum protein electrophoresis revealed Albumin $3.7 \mathrm{gm} \%$, globulins $4 \cdot 3 \mathrm{gm} \%$ and $\gamma$ globulins $\mathrm{I} \cdot 92-4 \cdot 3 \mathrm{gm} \%$. $\mathrm{H} \beta$ antigen negative. Serum $\mathrm{B}_{12}$ levels were normal. Serum folate $2 \mathrm{mcg} \%$, slightly low (5-2I mcg normal). LE preparation positive $\times 2$. Antinuclear antibodies test positive.

\section{Case 3}

This 23-year-old white female had onset of polyarthritis in 1969 and was being treated as rheumatoid arthritis. On 27 August she developed a severe headache, photophobia, nausea, vomiting, vertigo and dizziness. Neurological examination was reported to be normal. By 30 August 1972 the patient became febrile and comatose. She was treated with Decadron $8 \mathrm{mg}$ daily and approximately after a week she regained consciousness. She had marked nuchal rigidity, and loss of sensation and motor power below T4. Deep tendon reflexes in the lower extremities were absent. There was loss of bladder and bowel control. On auscultation a III/VI grade systolic murmur at the left sternal border was noted and radiographically there was a significant increase in cardiac size. Over a period of 6 weeks Decadron was gradually decreased to $0.5 \mathrm{mg}$ twice a day and her sensory level dropped to $\mathrm{T} 7$.

At the time of her admission at the Texas Institute for Rehabilitation and Research on Io October 1972, patient was completely motor paraplegic below $\mathrm{T}_{7}$, with preserved vibratory sensation in the lower limbs and patchy sensory preservation T9-I2 dermatomes. Three weeks after her admission, patient developed fever and headache. There was an erythematous rash over the cheeks and pinnae. Patient had complete sensory and motor loss below $\mathrm{T}_{7}$. Deep tendon reflexes were absent in the lower limbs but physiologic in the upper limbs. There was no Babinski sign. Cranial nerves were intact. Myelogram was reported to be normal. There was pericardial friction rub. She was treated with Medrol $80 \mathrm{mg} /$ day. Her course remained stable and at the time of her discharge she was totally independent in all activities of daily living and homemaking from the wheelchair level. Her steroids were gradually tapered and discontinued over a period of 4 months. In February 1973 patient developed thrombophlebitis. In February 1974, approximately I 8 months following the onset of paraplegia, patient had complete loss of sensation and loss of motor power below $\mathrm{T}_{7}$. Deep tendon reflexes were absent in the lower limbs.

Laboratory data: August 1972: several blood and CSF cultures negative. CSF (9-29-72): Proteins $39 \mathrm{mg} \%$, glucose $57 \mathrm{mg} \%$, WBC $\mathrm{I} / \mathrm{mm}^{3}$ and $\mathrm{RBC} 3 / \mathrm{mm}^{3}$. Repeat CSF (9-30-72) Protein $210 \mathrm{mg} \%$, sugar $15 \mathrm{mg} \%$, WBC were normal. Latex fixation test positive. LE prep. and ANA negative. Serum protein electrophoresis showed reversal of Albumin globulin ratio. EEG on 29 August 1972 showed poorly regulated, low voltage waves 5-IO/sec without localisation. Repeat EEG on 8 September 1972 reported to be normal. Brain scan normal. Myelogram was normal. 
Table I

Neurological findings in patients with SLE

\begin{tabular}{|c|c|c|c|c|c|c|c|c|c|c|}
\hline $\begin{array}{l}\text { Case } \\
\text { No. }\end{array}$ & $\begin{array}{l}\text { Age/ } \\
\text { sex }\end{array}$ & $\begin{array}{l}\text { Premyelopathy } \\
\text { symptoms }\end{array}$ & $\begin{array}{l}\text { Motor } \\
\text { level }\end{array}$ & $\begin{array}{l}\text { Sensory } \\
\text { level }\end{array}$ & DTRs & $\begin{array}{l}\text { Plantar } \\
\text { reflex }\end{array}$ & $\begin{array}{l}\text { Sphincter } \\
\text { control }\end{array}$ & $\begin{array}{l}\text { Myelo- } \\
\text { gram }\end{array}$ & Surgery/findings & Outcome \\
\hline I & $27 / \mathrm{BF}$ & $\begin{array}{l}\text { Periorbital oedema } \\
4 \text { wk. Pain in back, } \\
\text { severe, chills, nausea, } \\
\text { vomiting. Rash face }\end{array}$ & $\mathrm{C}_{5}$ & $\begin{array}{l}\text { C5 Vib. }+ \\
\text { Position }\end{array}$ & ० & ० & Lost & $\begin{array}{l}\text { Block T6-8 } \\
\text { and } \mathrm{C}_{5}-\mathrm{TI}_{\mathrm{I}}\end{array}$ & $\begin{array}{l}\text { Laminectomy. } \\
\text { Epidural fat pale. No } \\
\text { abnormality }\end{array}$ & $\begin{array}{l}\text { Tetraplegia } \\
\text { in }<20 \mathrm{hr} \\
\left(\mathrm{C}_{7}\right)\end{array}$ \\
\hline 2 & $53 / \mathrm{BF}$ & $\begin{array}{l}\text { Sore throat, chills, } \\
\text { fever, interscapular } \\
\text { pain and neck pain. } \\
\text { Hyperpigmentation }\end{array}$ & $\mathrm{T}_{5}$ & $\begin{array}{l}\text { T5 } \\
\text { Some } \\
\text { sensation } \\
+\end{array}$ & o & ० & Lost & Block Tro & $\begin{array}{l}\text { Laminectomy T7-IO. } \\
\text { Epidural fat } \\
\text { discoloured. No cord } \\
\text { abnormality }\end{array}$ & $\begin{array}{l}\text { Paraplegia in } \\
\text { I } 4 \mathrm{hr} \text { (TIO) }\end{array}$ \\
\hline$\star_{3}$ & $24 / \mathrm{WF}$ & $\begin{array}{l}\text { Arthritis, URI, } \\
\text { nausea, vomiting, } \\
\text { photophobia, fever, } \\
\text { vertigo, stiff neck, } \\
\text { rash }\end{array}$ & $\mathrm{T}_{4}$ & $\begin{array}{l}\text { T44 } \\
\text { Vib. }+\end{array}$ & o & $\ldots$ & Lost & Normal & $\ldots$ & $\begin{array}{l}\text { Complete } \\
\text { paraplegia } \\
<24 \mathrm{hr} \\
\left(\mathrm{T}_{7}\right)\end{array}$ \\
\hline$\star_{4}$ & $22 / \mathrm{WF}$ & $\begin{array}{l}\text { Abortion. Arthralgia, } \\
\text { fever, nausea, } \\
\text { vomiting, urinary } \\
\text { retention, neck } \\
\text { stiffness + + Rt. } \\
\text { Abducens palsy }\end{array}$ & TII & TII & ० & $\ldots$ & Lost & & $\ldots$ & $\begin{array}{l}\text { Paraplegia in } \\
<24 \mathrm{hr} \\
(\text { TII) }\end{array}$ \\
\hline
\end{tabular}

$+=$ present $\quad$ * Case Nos. 24, 25 of Table 2, reported by Andrianakos et al. (1975). 
November I972-CSF protein II $5 \mathrm{mg} \%$, glucose $45 \mathrm{mg} \%$, WBC $2 / \mathrm{mm}^{3}$ and $\mathrm{RBC} 240 / \mathrm{mm}^{3}$. Myelogram normal. ANA on three occasions weakly positive. Coomb's test negative. Anaemia and leucopenia present.

February I974-Anticytoplasmic antibodies positive I :64, latex positive I : I80. C3 complement.

Comment: Clinically this patient presented as meningoencephalomyelopathy rather than true transverse myelopathy.

\section{Case 4}

A 22-year-old white female was admitted at the Texas Institute for Rehabilitation and Research on 24 October 1973 for comprehensive rehabilitation. In September I97I she developed arthritis involving several joints of the left hand. Arthralgias occurred intermittently. In February 1973 she had a spontaneous abortion. During the following months, she had intermittent complaints of flank pain, neck soreness, dysuria and increased frequency, fatigue and weakness. She developed erythematous skin rash over the nasal bridge and cheeks. On 29 July 1973 she had nausea, vomiting, fever and neck stiffness along with acute retention of urine. Over the next several hours she noted numbness and weakness of legs and was unable to walk. At the time of her admission to the hospital her temperature was $102^{\circ} \mathrm{F}$. She had severe nuchal rigidity and VI cranial nerve palsy on the right. There was complete loss of sensation below TII and no voluntary motor activity in the lower extremities. Deep tendon reflexes were absent in the lower limbs and there were no pathologic reflexes. Patient was treated with prednisone $100 \mathrm{mg} /$ daily which was gradually reduced to $20 \mathrm{mg}$ every other day. At the time of her admission at TIRR, patient had complete sensory and motor loss below TI2. Deep tendon reflexes were absent in the lower limbs. Babinski sign was not present. Her hospital course was stable and the patient was independent in all activities of daily living and homemaking from the wheelchair. Patient was last seen at TIRR in February I974, I2 months after the onset of paralysis; there has not been any change in her motor status, with subtle sensory drop to $\mathrm{L}_{\mathrm{I}}$ on one side.

Laboratory data: CSF (7-30-73) Proteins $325 \mathrm{mg} \%$, glucose $18 \cdot 2 \mathrm{mg} \%$, WBC I48 with $60 \%$ polys. Repeat CSF (8-2-73) Protein $30 \mathrm{mg} \%$, glucose $32 \mathrm{mg} \%$, WBCs 700 with $82 \%$ polys and I $7 \%$ lymphos, RBC I6,000. (8-7-73) Protein I08 $\mathrm{mg} \%$, glucose $\mathrm{I} 5 \mathrm{mg} \%$, WBCs 249 with IO \% polys and 90\% lymphos, RBC 5749. (8-I3-73) Proteins $5 \mathrm{I} \mathrm{mg} \%$, glucose $47 \mathrm{mg} \%$, WBCs 5 lymphos, RBC ro5o. CSF cultures for fungus and acid fast bacilli were negative. Leucopenia was present. ANA positive $\times 3$. LE test was positive. RA Latex negative. Complement $\mathrm{C}_{3}$ normal, $\mathrm{C}_{4}$ low.

Comments: Clinical and laboratory findings in this patient were considered to be diagnostic of systemic lupus erythematosus. The presence of marked nuchal rigidity, nausea, vomiting and VI cranial nerve palsy along with paraplegia would be indicative of encephalomyelopathy rather than myelopathy alone.

\section{Discussion}

Systemic lupus erythematosus (SLE) is a clinical syndrome characterised by multisystem involvement with periods of exacerbations and remissions. The involvement of nervous system in these patients as reported in the literature ranges from I4 per cent to 75 per cent (Dubois, I974; Johnson and Richardson, 1968). It is hard to explain such a wide range which might be due in part to a short period of follow-up and partly dependent on the sophistication of the examiner. The exact frequency of paraplegia or tetraplegia cannot be estimated since there are only 26 cases of myelopathy associated with SLE previously 
reported in the literature. Two new cases are reported here, thus making a total of 28 cases of myelopathy with SLE. The diagnosis of systemic lupus erythematosus in these patients was made according to criteria set by the American Rheumatology Association and according to criteria proposed by Harvey and modified by Dubois (1974). We believe that there are probably many more unreported cases of myelopathy associated with SLE.

Since this series has only four cases of myelopathy with SLE, it would be worth while to review all 28 cases together to draw any meaningful conclusions about the spinal cord involvement. Of 2I patients, I8 were females and three were males (sex not reported for seven patients). Race was not stated for I4 patients. There were eight whites, five blacks and one Latin American. Seventeen of 25 patients (age not reported for three patients) were in the second, third and fourth decades of life, three (I I-20 years), nine ( $2 \mathrm{I}-30)$, five $(3 \mathrm{I}-40)$, two (4I-50), five $(5 \mathrm{I}-60)$ and one 62 years old.

The term 'myelopathy' or 'myelitis' has been inappropriately used by several authors in the literature to describe the neurological features of their patients with SLE since a number of patients had signs and symptoms of meningoencephalitis in addition to those of myelopathy or myelitis. Nausea, vomiting, photophobia, dizziness, vertigo, haemiparesis, nuchal rigidity and coma were present in six patients (Nos. 4, I6, I7, 20, 24, 25). Two patients (17, 25) had involvement of VI cranial nerve (abducens palsy). In addition significant neuropathological intracranial abnormalities on autopsy were detected in four patients (2, I4, I7, 20). We feel that these eight $(2,4, I 4, I 6, I 7,20,24,25)$ of the 26 previously reported cases should have been classified as meningoencephalomyelitis.

Myelopathy was the first manifestation of SLE in three patients $(4,7,28)$ and occurred as late as 23 years after the onset of SLE in two patients (I4, 22). Two patients $(7,27)$ developed involvement of other organ systems concommitant with the spinal cord involvement. One patient (4) developed multisystem disease two years after the involvement of the spinal cord. A diagnosis of systemic lupus erythematosus was not made prior to the onset of spinal cord involvement in II patients $(4,7,16,18,19,20,21,24,25,27,28)$ in spite of symptoms in another system in nine. Some of these patients were diagnosed as rheumatoid arthritis, fever of unknown origin and idiopathic thrombocytopenic purpura.

At the onset sudden interscapular and back pain along with neck pain were reported by eight patients $(7,16-18,21,25,27,28)$. In addition two patients $(5,17)$ developed paralysis over a period of several hours after severe abdominal pain. Acute retention of urine as initial neurological manifestation was present in four patients. Paresthesias, numbness and weakness of lower extremities were reported by is patients.

On admission two patients were tetraplegic, seven were paraparetic ( $\mathrm{LI}_{\mathrm{I}} \mathrm{S} 2$ ) and I9 were paraplegic (T2-TI2). Four paraplegic patients (I6, I8, I9, 2I) neurologically deteriorated and became tetraplegic. In addition three other paraplegic patients $(2, I 5, I 7)$ ascended from TII-TI2 levels to TI-2 and T6 level. Deep tendon reflexes in lower limbs were reported to be absent in II patients, hyperactive in three and hypoactive in two patients. In two other patients, paraplegia was described to be flaccid without any reference to tendon reflexes. Plantar responses could not be obtained in ten patients and extensor plantar response unilaterally or bilaterally were reported in seven patients. Loss of bladder and bowel control was reported in all 22 patients described in detail.

Myelogram was performed on Io patients. It was reported to be normal in 
Table II

Summary of clinical features, treatment, and outcome of 28 patients with myelopathy and SLE

\begin{tabular}{|c|c|c|c|c|c|c|c|c|c|c|c|c|c|c|}
\hline \multirow[t]{2}{*}{ Case } & \multirow[t]{2}{*}{ Authors(s) } & \multirow{2}{*}{$\begin{array}{l}\text { Age, } \\
\text { race, } \\
\text { sex }\end{array}$} & \multicolumn{7}{|c|}{ Neurological findings on admission } & \multirow[t]{2}{*}{ Treatment } & \multicolumn{3}{|c|}{ Duration } & \multirow[t]{2}{*}{ Outcome } \\
\hline & & & $\begin{array}{l}\text { Multi- } \\
\text { system } \\
\text { involve- } \\
\text { ment }\end{array}$ & $\begin{array}{l}\text { Presenting } \\
\text { symptoms of } \\
\text { myelopathy }\end{array}$ & $\begin{array}{c}\text { Time } \\
\text { deficit } \\
\text { evolved }\end{array}$ & $\begin{array}{l}\text { Motor } \\
\text { deficit }\end{array}$ & $\begin{array}{c}\text { Sensory } \\
\text { level }\end{array}$ & $\begin{array}{l}\text { Tendon } \\
\text { reflexes } \\
\text { in leg }\end{array}$ & $\begin{array}{c}\text { Extensor } \\
\text { plantar } \\
\text { responses }\end{array}$ & & $\begin{array}{l}\text { From onset } \\
\text { SLE to } \\
\text { myelopathy }\end{array}$ & $\begin{array}{l}\text { From onset } \\
\text { myelopathy } \\
\text { to treatment }\end{array}$ & $\begin{array}{l}\text { From onset } \\
\text { myelopathy } \\
\text { to outcome }\end{array}$ & \\
\hline I & $\begin{array}{l}\text { Fisher \& } \\
\text { Gilmour } \\
\text { (1939) }\end{array}$ & $33 \mathrm{~F}$ & + & $\begin{array}{l}\text { Fever and } \\
\text { headache, } \\
\text { stiff neck }\end{array}$ & 2 days & $\begin{array}{l}\text { Para- } \\
\text { plegia }\end{array}$ & $\begin{array}{l}T_{12} \\
\text { (T2) }\end{array}$ & - & - & None & $4 \mathrm{yr}$ & $\cdots$ & 4 days & Death \\
\hline 2 & $\begin{array}{l}\text { Piper } \\
\text { (I953) }\end{array}$ & $19 \mathrm{WF}$ & + & $\begin{array}{l}\text { Numbness } \\
\text { of legs, } \\
\text { weakness }\end{array}$ & I day & $\begin{array}{l}\text { Para- } \\
\text { paresis }\end{array}$ & Incomp. & $\downarrow$ & + & $\begin{array}{l}\text { (1) Cortisone } \\
75 \mathrm{mg} / \text { day } \\
\text { (2) ACTH } \\
\text { (3) Penicillin }\end{array}$ & $\cdots$ & $\begin{array}{l}\text { (I) Before } \\
\text { TM } \\
\text { (2), (3) Im- } \\
\text { mediately }\end{array}$ & 45 days & Death \\
\hline 3 & $\begin{array}{l}\text { Dubois } \\
\text { (1953) }\end{array}$ & 22 & $\cdots$ & $\cdots$ & $\cdots$ & $\begin{array}{l}\text { Para- } \\
\text { plegia }\end{array}$ & $\cdots$ & $\cdots$ & $\cdots$ & $\cdots$ & $\cdots$ & $\cdots$ & $\cdots$ & Death \\
\hline 4 & $\begin{array}{l}\text { Siekert \& } \\
\text { Clark } \\
\text { (I955) }\end{array}$ & $40 \mathrm{M}$ & + & $\begin{array}{l}\text { Numbness } \\
\text { and weakness } \\
\text { of legs, stiff } \\
\text { neck }\end{array}$ & I wk & $\begin{array}{l}\text { Para- } \\
\text { plegia }\end{array}$ & $\begin{array}{l}\mathrm{T}_{5} \\
\text { Incomp. }\end{array}$ & $\ldots$ & $\ldots$ & $\begin{array}{l}\text { Chloromy- } \\
\text { cetin } \\
\text { Penicillin }\end{array}$ & $\circ$ & $\ldots$ & $\begin{array}{l}\text { I } \frac{1}{2} \mathrm{mth}- \\
2 \mathrm{yrs}\end{array}$ & $\begin{array}{l}\text { Improved } \\
++ \\
\text { Ataxia }\end{array}$ \\
\hline 5 & $\begin{array}{l}\text { Weil } \\
\text { (I955) }\end{array}$ & $24 \mathrm{NF}$ & + & $\begin{array}{l}\text { Urinary } \\
\text { retention, } \\
\text { weakness of } \\
\text { legs, abd. } \\
\text { pain }\end{array}$ & I day & $\begin{array}{l}\text { Para- } \\
\text { plegia }\end{array}$ & $\mathrm{T}_{7}$ & $\cdots$ & $\ldots$ & $\begin{array}{l}\text { Streptomycin } \\
\text { Penicillin } \\
\text { Aureomycin }\end{array}$ & $7 \mathrm{yr}$ & Before TM & 2 days & Death \\
\hline 6 & $\begin{array}{l}\text { Armas-Cruz } \\
\text { et al. (1958) }\end{array}$ & $\cdots$ & $\cdots$ & ... & $\ldots$ & $\begin{array}{l}\text { Para- } \\
\text { plegia }\end{array}$ & & Flaccid & $\ldots$ & Cortisone & $\ldots$ & $\begin{array}{l}\text { I yr before } \\
\text { TM }\end{array}$ & $\ldots$ & $\begin{array}{l}\text { Improve- } \\
\text { ment }+\end{array}$ \\
\hline 7 & $\begin{array}{l}\text { Granger } \\
\text { (1960) }\end{array}$ & $25 \mathrm{NF}$ & + & $\begin{array}{l}\text { Paresthesias } \\
\text { in legs, } \\
\text { mid-scapular } \\
\text { pain }\end{array}$ & IO days & $\begin{array}{l}\text { Para- } \\
\text { paresis }\end{array}$ & $\begin{array}{l}\text { T2 (LI) } \\
\text { Incomp. }\end{array}$ & $\downarrow$ & - & $\begin{array}{l}\text { (I) Cortisone, } \\
300 \mathrm{mg} / \mathrm{day} \\
\text { (2) ACTH } \\
\text { (3) Prednisone, } \\
60 \mathrm{mg} \\
\text { (4) Chloroquine }\end{array}$ & ○ & $\begin{array}{l}\text { (I) Imme- } \\
\text { diately } \\
\text { (2) I wk } \\
\text { (3) } 5 \mathrm{wk} \\
\text { (4) } 9 \mathrm{wk}\end{array}$ & $2 \frac{1}{2}-5 \mathrm{mth}$ & Recovery \\
\hline 8 & $\begin{array}{l}\text { Poch } \\
\text { (1960) }\end{array}$ & $\cdots$ & $\cdots$ & $\cdots$ & $\cdots$ & $\begin{array}{l}\text { Para- } \\
\text { paresis }\end{array}$ & $\cdots$ & $\cdots$ & $\cdots$ & & $\cdots$ & $\cdots$ & $\ldots$ & $\begin{array}{l}\text { No } \\
\text { change }\end{array}$ \\
\hline 9 & $\begin{array}{l}\text { Mustata \& } \\
\text { Trica } \\
\text { (I960) }\end{array}$ & $28 \mathrm{~W}$ & + & $\begin{array}{l}\text { Weakness } \\
\text { of legs, } \\
\text { urinary } \\
\text { retention }\end{array}$ & I day & $\begin{array}{l}\text { Para- } \\
\text { plegia }\end{array}$ & $\cdots$ & - & - & $\begin{array}{l}\text { Cortisone, } \\
200 \mathrm{mg} / \text { day }\end{array}$ & $6 \mathrm{mth}$ & $\cdots$ & 80 days & $\begin{array}{l}\text { Improved } \\
++\end{array}$ \\
\hline Io & $\begin{array}{l}\text { Bas \& } \\
\text { Vachtencheim } \\
\text { (1963) }\end{array}$ & 36 & $\ldots$ & $\ldots$ & $\ldots$ & $\begin{array}{l}\text { Para- } \\
\text { paresis }\end{array}$ & $\cdots$ & $\cdots$ & $\cdots$ & $\cdots$ & $\ldots$ & $\ldots$ & $\cdots$ & $\begin{array}{l}\text { Improve- } \\
\text { ment }\end{array}$ \\
\hline II & $\begin{array}{r}(1963) \\
\ldots\end{array}$ & 62 & $\cdots$ & $\cdots$ & $\cdots$ & $\begin{array}{l}\text { Para- } \\
\text { paresis }\end{array}$ & $\cdots$ & $\cdots$ & $\cdots$ & $\cdots$ & $\cdots$ & $\cdots$ & $\cdots$ & $\begin{array}{l}\text { Improve- } \\
\text { ment }\end{array}$ \\
\hline 12 & $\begin{array}{l}\text { Orthner \& } \\
\text { Rosser } \\
\text { (1965) }\end{array}$ & $26 \mathrm{WM}$ & + & $\begin{array}{l}\text { Urinary in- } \\
\text { continence }\end{array}$ & 2 days & $\begin{array}{l}\text { Para- } \\
\text { plegia }\end{array}$ & $\mathrm{T}_{7}$ & $\ldots$ & $\ldots$ & $\begin{array}{l}\text { (I) Steroids } \\
\text { (2) ACTH }\end{array}$ & $9 \mathrm{yr}$ & $\begin{array}{l}\text { (I) Before } \\
T M\end{array}$ & 3 days & Death \\
\hline 13 & $\begin{array}{l}\text { Nasonova \& } \\
\text { Konchakova } \\
\text { (I965) }\end{array}$ & $\cdots$ & $\cdots$ & $\cdots$ & $\ldots$ & $\begin{array}{l}\text { Para- } \\
\text { paresis }\end{array}$ & $\cdots$ & $\cdots$ & $\cdots$ & $\cdots$ & $\cdots$ & $\cdots$ & $\cdots$ & $\begin{array}{l}\text { No } \\
\text { change } \\
\text { Para- } \\
\text { paresis }\end{array}$ \\
\hline I 4 & $\begin{array}{l}\text { Johns } \\
\text { Hopkins } \\
\text { Hospital } \\
\text { (I966) }\end{array}$ & $59 \mathrm{WF}$ & + & $\begin{array}{l}\text { Weakness } \\
\text { and } \\
\text { hypoesthesia } \\
\text { of legs }\end{array}$ & I day & $\begin{array}{l}\text { Para- } \\
\text { plegia }\end{array}$ & $\begin{array}{l}\text { Incomp. } \\
\text { loss }\end{array}$ & $\cdots$ & + & $\begin{array}{l}\text { Prednisone, } \\
60 \mathrm{mg} / \text { day }\end{array}$ & $23 \mathrm{yr}$ & $\begin{array}{l}4 \text { days } \\
\text { before TM }\end{array}$ & 35 days & Death \\
\hline
\end{tabular}




\begin{tabular}{|c|c|c|c|c|c|c|c|c|c|c|c|c|c|c|}
\hline 15 & $\begin{array}{l}\text { Johnson \& } \\
\text { Richardson } \\
\text { (1968) }\end{array}$ & $43 \mathrm{~F}$ & + & $\begin{array}{l}\text { Numbness } \\
\text { of legs, } \\
\text { urinary in- } \\
\text { continence }\end{array}$ & $4 \mathrm{mth}$ & $\begin{array}{l}\text { Para- } \\
\text { plegia }\end{array}$ & $\begin{array}{l}\mathrm{T}_{12} \\
(\mathrm{Tr})\end{array}$ & $\uparrow$ & + & $\begin{array}{l}\text { Cortisone, } \\
\text { roo mg/day }\end{array}$ & $6 \mathrm{mth}$ & Immediately & I $\mathrm{yr}$ & Death \\
\hline 16 & $\begin{array}{l}\text { Penn \& } \\
\text { Rowan } \\
\text { (I968) }\end{array}$ & $55 \mathrm{~F}$ & + & $\begin{array}{l}\text { Fever, mid- } \\
\text { scapular } \\
\text { pain } \\
\text { Horner's rt. }\end{array}$ & I day & $\begin{array}{l}\text { Para- } \\
\text { plegia } \\
\text { Tetra- } \\
\text { plegia }\end{array}$ & $\begin{array}{l}\mathrm{T} 8 \\
(\mathrm{C} 2)\end{array}$ & - & $\ldots$ & $\begin{array}{l}\text { Prednisone, } \\
40 \mathrm{mg} / \text { day }\end{array}$ & $20 \mathrm{yr}$ & $2 \mathrm{mth}$ & $34 \mathrm{mth}$ & Death \\
\hline I7 & $\ldots$ & II $\mathrm{F}$ & + & $\begin{array}{l}\text { Abd. and } \\
\text { back pain, } \\
\text { paresthesias } \\
\text { in legs, } \\
\text { abducens } \\
\text { palsy bilat., } \\
\text { stiff neck }\end{array}$ & $7 \mathrm{hr}$ & $\begin{array}{l}\text { Para- } \\
\text { plegia }\end{array}$ & $\begin{array}{l}\text { TII } \\
\text { (T6) }\end{array}$ & - & - & $\begin{array}{l}\text { Cortisone, } 50 \\
\text { to } 150 \mathrm{mg} / \mathrm{day}\end{array}$ & I $4 \mathrm{mth}$ & $\begin{array}{l}2 \mathrm{mth} \\
\text { before TM }\end{array}$ & I4 days & Death \\
\hline 18 & $\ldots$ & $12 \mathrm{~F}$ & + & $\begin{array}{l}\text { Midscapular } \\
\text { pain, } \\
\text { numbness, } \\
\text { weakness of } \\
\text { legs }\end{array}$ & I day & $\begin{array}{l}\text { Para- } \\
\text { plegia } \\
\text { Tetra- } \\
\text { plegia }\end{array}$ & $\begin{array}{l}\mathrm{T}_{4} \\
\text { (C6) } \\
\text { Incomp. }\end{array}$ & $\uparrow$ & + & $\begin{array}{l}\text { Dexametha- } \\
\text { sone, } \\
24 \mathrm{mg} / \text { day }\end{array}$ & $6 \mathrm{yr}$ & 4 days & $13 \mathrm{mth}$ & $\begin{array}{l}\text { Paraplegia } \\
\text { T6? }\end{array}$ \\
\hline 19 & $\ldots$ & $35 \mathrm{~F}$ & + & $\begin{array}{l}\text { Numbness } \\
\text { of legs, Rt. } \\
\text { Horner } \\
\text { syndrome }\end{array}$ & $2 \mathrm{wk}$ & $\begin{array}{l}\text { Para- } \\
\text { plegia } \\
\text { Tetra- } \\
\text { paresis }\end{array}$ & $\begin{array}{l}\mathrm{T}_{4} \\
\left(\mathrm{C}_{7}\right)\end{array}$ & - & - & $\begin{array}{l}\text { Prednisone, } \\
80 \mathrm{mg} / \text { day }\end{array}$ & I mth & $8 \mathrm{mth}$ & $2 \mathrm{yr}$ & $\begin{array}{l}\mathrm{C}_{7} \\
\text { Tetra- } \\
\text { plegia }\end{array}$ \\
\hline 20 & $\begin{array}{l}\text { Sinkovics } \\
\text { et al. (1969) }\end{array}$ & 33 LAM & + & $\begin{array}{l}\text { Numbness } \\
\text { of legs, neck } \\
\text { stiffness }\end{array}$ & gradual & $\begin{array}{l}\text { para- } \\
\text { plegia }\end{array}$ & Tio & Flaccid & $\ldots$ & $\begin{array}{l}\text { (I) Steroids } \\
\text { (2) Cyclophos- } \\
\text { phamide }\end{array}$ & $6 \mathrm{yr}$ & $\begin{array}{l}\text { (I) } 20 \text { days } \\
\text { (2) } 30 \text { days }\end{array}$ & 35 days & Death \\
\hline $2 \mathrm{I}$ & $\begin{array}{l}\text { Castaing } \\
\text { et al. (1970) }\end{array}$ & 4I WF & + & $\begin{array}{l}\text { Acute low } \\
\text { back pain }\end{array}$ & I day & $\begin{array}{l}\text { Para- } \\
\text { plegia }\end{array}$ & $\begin{array}{l}\text { T6 } \\
\text { (C6) }\end{array}$ & - & - & Prednisone & $3 \mathrm{yr}$ & $\cdots$ & 20 days & Death \\
\hline 22 & $\begin{array}{l}\text { Andrews } \\
\text { et al. }(1970)\end{array}$ & $51 \mathrm{~F}$ & + & $\begin{array}{l}\text { Numbness } \\
\text { of legs }\end{array}$ & I wk & $\begin{array}{l}\text { Para- } \\
\text { plegia } \\
\text { Tri- } \\
\text { plegia }\end{array}$ & $\begin{array}{l}\text { T8 } \\
\text { Incomp. }\end{array}$ & $\uparrow$ & + & $\begin{array}{l}\text { Prednisone } \\
\text { Coumadin }\end{array}$ & $23 \mathrm{yr}$ & $\cdots$ & $20 \mathrm{mth}$ & Death \\
\hline 23 & $\begin{array}{l}\text { Vitale et al. } \\
\text { (1973) }\end{array}$ & $23 \mathrm{WF}$ & + & $\begin{array}{l}\text { Urinary } \\
\text { retention }\end{array}$ & I day & $\begin{array}{l}\text { Tetra- } \\
\text { plegia }\end{array}$ & $\mathrm{C}_{5}$ & $\cdots$ & + & Steroids & $13 \mathrm{yr}$ & $\begin{array}{l}\text { Imme- } \\
\text { diately }\end{array}$ & I mth & Recovery \\
\hline 24 & $\begin{array}{l}\text { Andrianakos } \\
\text { et al. (1975) }\end{array}$ & $24 \mathrm{WF}$ & + & $\begin{array}{l}\text { Fever and } \\
\text { headache }\end{array}$ & I day & $\begin{array}{l}\text { Para- } \\
\text { plegia }\end{array}$ & $\begin{array}{l}\mathrm{T}_{4} \\
\text { (T8) } \\
\text { Incomp. }\end{array}$ & - & - & $\begin{array}{l}\text { Decadron, } \\
8 \text { mg/day }\end{array}$ & $3 \mathrm{yr}$ & $\begin{array}{l}\text { Imme- } \\
\text { diately }\end{array}$ & I6 mth & $\begin{array}{l}\text { Para- } \\
\text { plegia } \\
\text { T8 }\end{array}$ \\
\hline 25 & $\ldots$ & $22 \mathrm{WF}$ & + & $\begin{array}{l}\text { Urinary } \\
\text { retention, } \\
\text { Rt. abducens } \\
\text { palsy, neck } \\
\text { stiffness }\end{array}$ & 2 days & $\begin{array}{l}\text { Para- } \\
\text { plegia }\end{array}$ & $\begin{array}{l}\text { TII } \\
(\mathrm{LI})\end{array}$ & - & - & $\begin{array}{l}\text { Prednisone, } \\
\text { I00 } \mathrm{mg} / \text { day }\end{array}$ & $2 \mathrm{yr}$ & I day & $12 \mathrm{mth}$ & $\begin{array}{l}\text { Para- } \\
\text { plegia } \\
\text { TI2 }\end{array}$ \\
\hline 26 & . & $56 \mathrm{NF}$ & + & $\begin{array}{l}\text { Numbness } \\
\text { of legs }\end{array}$ & 3 days & $\begin{array}{l}\text { Para- } \\
\text { paresis }\end{array}$ & T6 & - & + & $\begin{array}{l}\text { Prednisone, } \\
60 \mathrm{mg} / \mathrm{day}\end{array}$ & $3 \mathrm{yr}$ & I day & 40 days & Death \\
\hline 27 & TIRR & $27 \mathrm{BF}$ & + & $\begin{array}{l}\text { Inter- } \\
\text { scapular } \\
\text { pain, numb- } \\
\text { ness and } \\
\text { tingling of } \\
\text { lower limbs }\end{array}$ & $20 \mathrm{hr}$ & $\begin{array}{l}\text { Tetra- } \\
\text { plegia } \\
\text { C5 }\end{array}$ & $\begin{array}{l}\text { C7 } \\
\text { Vib. + } \\
\text { Position } \\
+\end{array}$ & - & - & $\begin{array}{l}\text { (1) Penicillin } \\
\text { (2) Lamin- } \\
\text { ectomy } \\
\text { (3) Prednisone }\end{array}$ & I mth & $\begin{array}{l}\text { (I) Before } \\
\text { myelo- } \\
\text { pathy } \\
\text { (2) Imme- } \\
\text { diately } \\
\text { (3) } 3 \text { weeks }\end{array}$ & $5 \mathrm{mth}$ & $\begin{array}{l}\text { Tetra- } \\
\text { plegia } C_{7}\end{array}$ \\
\hline 28 & TIRR & $53 \mathrm{BF}$ & + & $\begin{array}{l}\text { Inter- } \\
\text { scapular and } \\
\text { neck pain, } \\
\text { numbness in } \\
\text { lower limbs }\end{array}$ & $<24 \mathrm{~h}$ & $\begin{array}{l}\text { Para- } \\
\text { plegia } \\
\mathrm{T}_{5}\end{array}$ & $\begin{array}{l}\text { T5 } \\
\text { Touch }+ \\
\text { Pressure } \\
+\end{array}$ & - & - & $\begin{array}{l}\text { (I) Lamin- } \\
\text { ectomy } \\
\text { (2) Prednisone }\end{array}$ & $\circ$ & $\begin{array}{l}\text { (I) Imme- } \\
\text { diately } \\
\text { (2) weeks }\end{array}$ & ro mth & $\begin{array}{l}\text { Para- } \\
\text { plegia } \\
\text { T5 }\end{array}$ \\
\hline
\end{tabular}


seven and abnormal in three patients $(20,27,28)$. Irregular filling defect from $\mathrm{T}_{4}-\mathrm{LI}$ was noted in Case 20, and this patient on laminectomy was found to have blood clots in veins. One patient (27) had a partial block T6-8 and complete block C5-Ti. Another patient (28) had a complete block at T8. Both these patients underwent laminectomy, because of the abnormalities on myelogram, on the days of admission and there was no evidence of obstruction on surgery; in both patients epidural fat was reported to be pale and discoloured. Thus myelograms in these three cases were false positive.

Sixteen of the 28 patients with myelopathy and SLE had CSF protein determinations. CSF protein values were reported to be elevated in I4 patients at least on one occasion and values greater than $100 \mathrm{mg} \%$ were found in $\mathrm{I} 2$ patients. Only two patients $(18,22)$ had normal levels of CSF proteins. CSF glucose levels were determined in $\mathrm{I} 2$ patients, in seven patients levels were less than $40 \mathrm{mg} \%$ at least on one occasion and in five of these levels were less than $30 \mathrm{mg} \%$. CSF glucose levels on the day of development of myelopathy were determined and found to be low in six patients (13,24-28). Andrianakos et al. (1975) suggested that low CSF glucose levels during the actute stage of transverse myelopathy are observed only in patients with SLE. In myelopathy due to vascular causes other than SLE, CSF glucose levels immediately after the onset of paralysis have been reported to be normal (Hill and Vasquez, I962; Hughes and MacIntyre, I963; Herrick and Mills, I97I). Similarly CSF proteins levels in patients with spinal cord infarction caused by vascular diseases other than SLE, have been reported to be normal (Hill and Vasquez, 1962; Hughes and MacIntyre, 1963; Herric and Mills, I97I; Gerland et al., I966; Wolman and Bradshaw, I967; Laguna and Gravioto, I973). It seems that this combination of elevated cerebrospinal fluid, proteins and low glucose level during acute stage is characteristic of myelopathy associated with SLE.

LE cells were observed in 19 patients and absent in two cases (12, 24). Antinuclear antibodies were present in nine of the tested ten cases. Anticytoplasmic antibodies were tested and found positive in one patient. In several cases LE preparation and antinuclear antibodies were absent when patients were on heavy doses of steroids or during stage of low activity of SLE but subsequently one or both these tests became positive.

Of the I5 patients who survived, two were tetraplegic (19, 27). Three patients with paraplegia $(4,7,9)$ and one with tetraplegia $(23)$ showed considerable neurological improvement in I to 6 months after the onset of transverse myelopathy and were ambulatory with minimal sensory and motor deficit. Three patients (6, IO, I I) who were paraplegic/paretic to start with showed some improvement. Six patients $(8,13,18,24,25,28)$ remained stable paraplegic without any significant sensory motor return.

Thirteen of 28 patients died in 2 days to 34 months after the onset of myelopathy and nine of these died within 45 days. Four patients died of septicaemia, two of pneumonia, one each from pulmonary embolism and pulmonary oedema. Two patients with widespread vasculitis developed haemorrhages-cerebral and intra-abdominal from mesenteric artery aneurysm and died. Autopsies were performed on I2 of I3 patients who died with myelopathy and SLE. Histopathologic findings of central nervous system are summarised in Table IV. Intracranial abnormalities varied from a few minute infarcts of brain, fresh and resolving haemorrhages to encephalomalacia. There was evidence of vasculitis and perivascular demyelination as well. Significant intracranial histologic abnormalities were reported in four patients. Vascular changes in the spinal cords of I I 
Table III

Laboratory data for 22 patients with myelopathy and systemic lupus erythematosus

\begin{tabular}{|c|c|c|c|c|c|c|c|c|c|c|c|}
\hline \multirow{3}{*}{$\begin{array}{l}\text { Patient } \\
\text { No. }\end{array}$} & \multirow[t]{2}{*}{ Haemoglobin } & \multirow[t]{2}{*}{ Leucocytes } & \multirow{2}{*}{$\begin{array}{l}\text { Antinuclear } \\
\text { antibodies }\end{array}$} & \multirow{2}{*}{$\begin{array}{l}\text { Lupus } \\
\text { erythematosus } \\
\text { cells }\end{array}$} & \multirow{2}{*}{$\begin{array}{l}\text { Urine } \\
\text { protein }\end{array}$} & \multicolumn{5}{|c|}{ Cerebrospinal fluid } & \multirow[t]{2}{*}{ Myelogram } \\
\hline & & & & & & Protein & Glucose & Leucocytes & Erythrocytes & Cultures & \\
\hline & $\mathrm{gm} / \mathrm{dl}$ & $\times \mathrm{IO}^{3} / \mathrm{mm}^{3}$ & $-\cdots \cdots-\cdots$ & $-\ldots-$ & $--\cdots$ & \multicolumn{2}{|c|}{$\mathrm{mg} / \mathrm{dl}$} & \multicolumn{2}{|c|}{ no. $/ \mathrm{mm}^{3}$} & . & - - - \\
\hline$\star_{I}$ & $\downarrow$ & $5 \cdot 7$ & $\ldots$ & $\ldots$ & $\ldots$ & 100 & $\ldots$ & 16,100 & Few & Negative & $\ldots$ \\
\hline$\star_{2}$ & $\ldots$ & Leucopenia & $\ldots$ & + & + & I75 & 39 & I 6 & $\ldots$ & ... & $\ldots$ \\
\hline 4 & II 4 & 3.8 & $\ldots$ & + & + & $\ldots$ & $\cdots$ & $\ldots$ & $\ldots$ & $\cdots$ & $\ldots$ \\
\hline${ }^{\star} 5$ & $7 \cdot 7$ & 6.9 to $23 \cdot 0$ & $\ldots$ & + & + & $\ldots$ & Normol & $\cdots$ & & $\cdots$ & $\cdots$ \\
\hline 7 & Normal & $<5.0$ & $\ldots$ & + & + & 152 & Normal & $\cdots_{7}$ & Few & Negative & $\cdots$ \\
\hline $\begin{array}{r}9 \\
\star 12\end{array}$ & $\downarrow$ & 3.5 & $\cdots$ & + & + & $\ldots$ & $\ldots$ & 7 & $\cdots$ & $\cdots$ & $\cdots$ \\
\hline $\begin{array}{l}\star_{12} \\
\star_{14}\end{array}$ & $\dddot{\downarrow}$ & $\begin{array}{c}4 \cdot 2 \text { to } 10 \cdot 2 \\
2 \cdot 4\end{array}$ & $\begin{array}{l}\ldots \\
\ldots\end{array}$ & $\overrightarrow{+}$ & $\dddot{x}$ & $\begin{array}{l}53 \\
\ldots\end{array}$ & $\begin{array}{l}20 \\
\ldots\end{array}$ & $\ldots^{39}$ & $\cdots$ & $\cdots$ & $\cdots$ \\
\hline$\star_{15}$ & $\ldots$ & Leucopenia & $\cdots$ & + & + & 40 & $\cdots$ & 7 & $\ddot{3}$ & $\begin{array}{l}\cdots \\
\cdots\end{array}$ & Normal \\
\hline$\star_{16}$ & 9.8 to 10.6 & $5 \cdot 5$ & $2+$ & + & + & $\begin{array}{r}192 \\
136 \\
70 \\
22\end{array}$ & $\begin{array}{l}50 \\
50 \\
58\end{array}$ & $\begin{array}{r}400 \\
18 \\
1\end{array}$ & $\begin{array}{l} \\
\ldots \\
\ldots \\
\ldots\end{array}$ & $\begin{array}{l}\text { Negative } \\
\text { Negative } \\
\text { Negative }\end{array}$ & $\begin{array}{c}\text { Normal } \\
\ldots \\
\ldots\end{array}$ \\
\hline${ }^{\star} I_{7}$ & 7 to 8 & $4 \cdot 0$ & $\cdots$ & + & + & $\begin{array}{l}22 \\
\cdots\end{array}$ & $\begin{array}{l}50 \\
\cdots\end{array}$ & $\cdots$ & $\begin{array}{l}\text { Dark } \\
\text { blood }\end{array}$ & p. & $\cdots$ \\
\hline I 8 & 9.8 to IO. I & $2 \cdot 5$ & $3+$ & + & + & 43 & 68 & 16 & $\ldots$ & $\cdots$ & $\ldots$ \\
\hline I9 & $9 \cdot 6$ to $\mathrm{II} \cdot \mathrm{I}$ & $3 \cdot 7$ & $3+$ & + & + & $\begin{array}{c}340 \\
69\end{array}$ & 46 & $\uparrow_{22}$ & $\cdots$ & $\cdots$ & Normal \\
\hline$\star_{20}$ & I0. 8 & $6 \cdot 8$ & + & + & $\ldots$ & $\ldots$ & $\ldots$ & $\ldots$ & $\ldots$ & $\ldots$ & Abnormal \\
\hline$\star^{*} \mathrm{I}$ & $\downarrow$ & $2 \cdot 0$ to $8 \cdot 0$ & $\ldots$ & + & + & $\begin{array}{l}140 \\
200\end{array}$ & $\ldots$ & $\begin{array}{r}4 \mathrm{I} 3 \\
\mathrm{I}\end{array}$ & $\ldots$ & $\ldots$ & $\cdots$ \\
\hline$\star_{22}$ & Normal & 13.7 & - & + & $\cdots$ & $\begin{array}{l}\text { Normal } \\
46\end{array}$ & $\dddot{75}$ & $\begin{array}{r}27 \\
2\end{array}$ & $\ldots$ & $\cdots$ & Normal \\
\hline 23 & $\ldots$ & Leucopenia & I : 100 & + & $\ldots$ & 150 & $\ldots$ & 49 & $\cdots$ & $\ldots$ & $\ldots$ \\
\hline 24 & $\mathrm{IO} \cdot 5$ to $\mathrm{II} \cdot \mathrm{I}$ & 2.8 to 3.8 & $t$ & $\cdots$ & - & $\begin{array}{r}39 \\
210\end{array}$ & $\begin{array}{l}57 \\
15\end{array}$ & I & 3 & Negative & Normal \\
\hline & & & & & & $\begin{array}{r}71 \\
115\end{array}$ & 43 & $\begin{array}{l}2 \\
2\end{array}$ & $\begin{array}{r}44 \\
240\end{array}$ & & \\
\hline 25 & $9 \cdot 0$ to 10.9 & $2 \cdot 2$ to $3 \cdot 4$ & I : 64 & + & - & 325 & 18 & $\mathrm{I} 48$ & 2580 & Negative & Normal \\
\hline$\star_{2} 6$ & 12.5 & $6 \cdot I$ & I $: 64$ & + & + & II 5 & 25 & IO & 95 & Negative & Normal \\
\hline 27 & $8 \cdot 8$ & 4.9 & + & + & + & 88 & 29 & $\begin{array}{l}700 \\
\mathrm{P} 80 \%\end{array}$ & $\cdots$ & Negative & $\begin{array}{l}\text { Block-C5 } \\
\text { T6-T8 }\end{array}$ \\
\hline 28 & 5.9 to 8.0 & 4.0 to $7 \cdot 6$ & I $: 8$ & + & + & 585 & $3 I$ & $\begin{array}{r}425 \\
\mathrm{P}_{50} \%\end{array}$ & $\ldots$ & $\ldots$ & $\begin{array}{l}\text { Block- } \\
\text { Tro }\end{array}$ \\
\hline
\end{tabular}


TABLE IV

Summary of histopathologic findings in spinal cords of patients with myelopathy and SLE

\begin{tabular}{cl}
\hline Case No. & \multicolumn{1}{c}{ Findings } \\
2 & $\begin{array}{l}\text { Myelomalacia. Microhaemorrhages in the spinal cord. Vasculitis and } \\
\text { thrombosis of small vessels TI2-L2. } \\
\text { Ischaemic necrosis of the lumbar segments of the spinal cord. Vasculitis } \\
\text { and thrombosis of meningeal vessels. } \\
\text { Acute arteritis in the spinal cord with oedema of the surrounding tissue. } \\
\text { Subdural spinal haematoma (T4-L3) with cord compression. Necrosis of } \\
\text { spinal cord. } \\
5\end{array}$ Microhaemorrhages in the spinal cord midcervical to midthoracic region. \\
I2 & $\begin{array}{l}\text { Evidence of vasculitis present. } \\
\text { Subdural spinal haematoma along lower portion of the cord and multiple } \\
\text { haemorrhages within the substance of the spinal cord. }\end{array}$ \\
I5 & $\begin{array}{l}\text { Subacute degeneration of the white matter from midcervical to sacral } \\
\text { segments. Thickening of the adventitia of small arteries and veins in the } \\
\text { region of degeneration. }\end{array}$ \\
I7 & $\begin{array}{l}\text { Myelomalacia of the thoracic and lumbar segments of the spinal cord. } \\
\text { Microhaemorrhages in the cord. } \\
\text { Thrombosis of anterior spinal artery. Infarction of lumbar segments of the }\end{array}$ \\
20 & $\begin{array}{l}\text { spinal cord. } \\
\text { Infarction of thoracic and lumbar segments. Perivascular infiltrates. }\end{array}$ \\
22 & $\begin{array}{l}\text { Necrotising myelitis of thoracic and lumbar segments without vascular } \\
\text { occlusion or malformation. } \\
\text { Massive necrosis of the midthoracic segments of the spinal cord. Throm- } \\
\text { botic occlusion of small leptomeningeal vessels. Perivascular infiltrate of } \\
\text { lymphocytes around small blood vessels. }\end{array}$ \\
\hline
\end{tabular}

patients were reported. Nine patients had neuropathologic evidence of myelomalacia, necrosis or infarction of the spinal cord, and two patients had evidence of vasculitis only without infarction (3, I2). Subdural spinal haematoma with compression and necrosis of the spinal cord were seen in two cases (5, 14). One patient had degeneration of white matter and thickening of the adventitia of small arteries and another patient had myelopathy without vascular occlusion or malformation. Pervascular round cell infiltration and connective tissue proliferation, thrombotic occlusion of small arteries and arterioles as well as microhaemorrhages in the cord parenchyma were similar to those found in other major organs.

Andrianakos et al. (1975) speculated the beneficial effects of steroids therapy within 24 hours of the onset of myelopathy and Granger (1960) speculated on the efficacy of chloroquine but Siekert's (I955) patient improved without chloroquine or steroid therapy. Records of detailed treatment were available for 23 patientsI2 died and I I survived. Six patients (7, I 5, 23, 24, 25, 26) were treated with steroids within the first 24 hours after the onset of myelopathy. Four survived and two of these showed good recovery. Among I 7 other patients three did not receive steroids, five were treated later, five were on low to moderate doses of steroids before the onset of myelopathy and four were given steroids at an unspecified interval after the onset of myelopathy. Only seven of these survived and 
two made good recovery. From these data it is hard to say if steroid therapy made any significant difference, although there is some suggestion that there was higher mortality $(60 \%)$ in this latter group and comparatively smaller number of surviving patients showed any neurological improvement. Since the number of cases in each group was small, no statistically valid conclusions could be drawn. However, immediate treatment of myelopathy with steroids does not appear to be a sound practice since myelomalacia, ischaemic myelopathy or haemorrhages in the substance of the spinal cord would not be altered by steroids.

In patients with clinical picture of myelopathy of sudden onset, in the absence of any history of trauma, systemic lupus erythematosus should be considered in the differential diagnosis.

\section{Summary}

Two patients with sudden onset of myelopathy associated with systemic lupus erythematosus are described in detail. Both patients were found to have block on myelography and underwent exploratory laminectomy. No spinal cord pathology was found on surgery except slightly thickened dura and pale epidural fat. Pertinent literature is extensively reviewed and these two new patients are added to previously reported 26 patients. It is suggested that in patients with sudden onset of myelopathy, in the absence of any history of trauma, systemic lupus erythematosus should be considered in the differential diagnosis.

\section{RÉSUMÉ}

Deux malades avec une myélopathie qui s'est declarée soudainement, sont décris en detail. Une myélographie montrant un bloc pour les deux sujets, ils furent soumis a une laminectomie d'exploration. Excepté pour une dure mère légèrement épaissie, et une graisse épidural pale, one ne trouva pas de pathologie de la moëlle epinière. Les publications sur ce sujet sont revues et ces deux malades sont ajoutés a la liste des 26 malades déja décris. L'auteur pense que chez des malades montrant une myélopathie soudaine en l'absence d'un trauma, on devrait inclure le lupus érythemateux systémique dans les diagnostiques possibles.

\section{ZUSAMMENFASSUNG}

Die Fälle von 2 Patienten, die plötzlich an myelopathie, in Verbindung mit Systemischen Lupus Erythomatosus, erkranken, wird hier beschrieben.

Beide Patienten zeighten einen Block in der myelographie und wurden deshalb einer exploratie von laminectomie unterzogen. Mit Ausnahme einer leicht verdickten dura und einem spärlich durchbluteten epiduralen Fettklumpen konnten bei der Operation keine pathologischen Befunde erhoben werden. Die einschlägige Literatur wird sehr ausfürlich besprochen und die 2 neuen Patienten werden zu den 26 früher berichteten Fällen angefügt. Es wird vorgeschlagen, dass man bei Patienten, die plötzlich an einer myelopathy erkranken, lupus erythematosus in die differential Diagnose einschliesst, wenn in der Krankengeschichte ein Unfall ausgeschlossen werden kann.

\section{REFERENCES}

Andrews, J. M. \& Cancilla, P. A. (1970). Progressive spinal cord signs in a patient with disseminated lupus erythematosus. Bull. Los Angeles Neurol. Soc., 35, 78-85.

AndRIANAKos, A. A., DufFy, J., Suzuki, M. \& Sharp, J. T. (I975). Transverse myelopathy in systemic lupus erythematosus. Report of three cases and review of the literature. Ann. Intern. Med., 83, 616-624.

Armas-Cruz, R., Harnecker, J., DUCaCh, G., et al. (1958). Clinical diagnosis of systemic lupus erythematosus. Am. F. Med., 25, 409-4I9.

Bas, H. \& VACHTENHEIM, J. (I963). Neurologische erscheinungenbeim systematischen lupus erythematodes. Dtsch. Z. Nervenheilkde, 185, 244-25I.

$16 / 3-E$ 
Castaing, R., Vital, C., Cardinaud, J. P., et al. (I970). Ramollissement medullaire au cours d'un lupus erythemateux dissemine. Etude anatomoclinique d'une observation. Bordeaux Med., 3, 707-718.

Clinicopathologic Conference (1966). Bull. Fohns Hopkins Hosp., 1 18, 423-437.

DuBoIs, E. L. (1953). The effect of LE cell test on the clinical picture of systemic lupus erythematosus. Ann. Intern. Med., 38, I265-I294.

Dubors, E. L. (1974). The clinical picture of systemic lupus erythematosus. In Lupus Erythematosus. University of Southern California Press, Los Angeles, 2nd edition.

Fisher, J. H. \& Gilmour, J. R. (1939). Encephalomyelitis following administration of sulphanilamide. Lancet, 2, 30I-305.

GERLAND, H., GREENBERG, J. \& HARRIMAN, D. G. F. (I966). Infarction of the spinal cord. Brain, 89, 645-662.

GRANGER, D. P. (1960). Transverse myelitis with recovery: the only manifestation of systemic lupus erythematosus. Neurology, 10, 325-329.

Herrick, M. D., Mills, Jr., P. E. (I97I). Infarction of spinal cord. Two cases of selective gray matter involvement secondary to asymptomatic aortic disease. Arch. Neurol., 24, 228-24I.

Hill, Jr., C. S. \& VASQUEZ, J. M. (I962). Massive infarction of spinal cord and vertebral bodies as a complication of dissecting aneurysm of the aorta. Circulation, 25, 997-1000.

Hughes, J. T. \& MACINTYRE, A. G. (1963). Spinal cord infarction occurring during thoracolumbar sympathectomy. F. Neurol. Neurosurg. Psychiatry, 26, 4I8-42 I.

Johnson, R. T. \& Richardson, E. P. (I968). Neurological manifestations of systemic lupus erythematosus. A clinical-pathological study of 24 cases and review of the literature. Medicine (Baltimore), 47, 337-369.

Kaposi, M. K. (I872). Nene Beitrage Zur Kenntniss des lupus erythematosus. Arch. Dermatol. Syph., 4, 36-78.

Laguna, J. \& GRAvioto, H. (I973). Spinal cord infarction secondary to occlusion of the anterior spinal artery. Arch. Neurol., 28, 134-136.

Mustata, N. \& Trica, L. (I960). Lupus eritematos diseminat cu manifestari neurologice. Viata Med., 7, 455.

Nasonova, V. A. \& Konchakova, M. I. (1965). The course of systemic lupus erythematosus with neurological syndromes. Vopr. Reum., 5, I2-I6.

ORTHNER, H. \& ROSSNER, R. (1965). Chronisch rezidivierender lupus erythematodes visceralis mit akut todlicher zentralnervoser exacerbation. Dtsch. Z. Nervenheilkde, $187, \mathrm{I}-24$.

OSLER, W. (1903). On the visceral manifestations of the erythema group of skin diseases. Trans. Assoc. Am. Physicians, 18, 599-624.

Penn, A. S. \& Rowan, A. J. (I968). Myelopathy in systemic lupus erythematosus. Arch. Neurol., 18, 337-349.

Piper, P. G. (I953). Disseminated lupus erythematosus with involvement of the spinal cord. F. Am. Med. Assoc., 153, 21 5-217.

Poch, G. F. (I960). Enfermedades del colageno. Manifestations Neurologicas, musculares y psiquiatricas. Buenos Aires, Lopes Libreros Editores SRL.

SIEKERT, R. G. \& CLARK, E. C. (I955). Neurologic signs and symptoms as early manifestations of systemic lupus erythematosus. Neurology, 5, 84-88.

Sinkovics, J. G., Gyorkey, F. \& ThomA, G. W. (I969). A rapidly fatal case of systemic lupus erythematosus: structure resembling viral nucleoprotein strands in the kidney and activities of lymphocytes in culture. Texas Rep. Biol. Med., 27, 887-908.

Vitale, C., Kahn, M. F., De Seze, M. \& De Seze, S. (I973). Nevrite optique, myelite maladie lupique. A propos de deux observations. Ann. Med. Interne (Paris), 124, 2 II -216.

WeIL, M. H. (1955). Disseminated lupus erythematosus with massive hemorrhagic manifestations and paraplegia. F. Lancet, 75, 358-360.

Wolman, L. \& BRadShaw, P. (1967). Spinal cord embolism. F. Neurol. Neurosurg. Psychiatry, 30, 446-454. 